Revista Brasileira de Farmacognosia Brazilian Journal of Pharmacognosy 22(3): 558-567, May/Jun. 2012

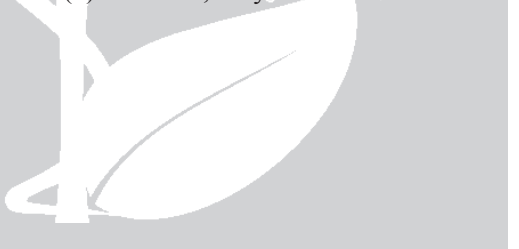

Article

Received 24 Jul 2011

Accepted 30 Dec 2011

Available online 8 Mar 2012

Keywords:

Moroccan propolis

cytotoxicity

in vitro

in vivo

DBA2 mice

tumor cells

ISSN 0102-695X

http://dx.doi.org/10.1590/S0102-

695X2012005000030

\section{Evaluation of the in vitro and in vivo anticancer properties of Moroccan propolis extracts}

\author{
Hassan Ait Mouse, ${ }^{1}$ Mounir Tilaoui, ${ }^{1}$ Abdeslam Jaafari, ${ }^{1}$ \\ Lahcen Ait M'barek, ${ }^{1}$ Rachida Aboufatima, ${ }^{1}$ Abderrahmane \\ Chait, $^{2}$ Abdelmajid Zyad ${ }^{*}$
}

\author{
${ }^{1}$ Laboratory of Biological Engineering. Natural Substances, Cellular and \\ Molecular Immuno-pharmacology Group, Sultan Moulay Slimane University; \\ Faculty of Science and Technology, Morocco, \\ ${ }^{2}$ Laboratory of Ecophysiology, Cadi Ayyad University, Faculty of Sciences \\ Semlalia, Marrakech, Morocco.
}

\begin{abstract}
This investigation aimed to evaluate the in vitro and in vivo antitumor potential of a Moroccan propolis extracts. For in vitro assays, three mammalian tumor cell lines were used: BSR (hamster renal adenocarcinoma), Hep-2 (human laryngeal carcinoma) and P815 (murin mastocytoma). The propolis ethanolic extract as well as the ethyl acetate extract, exert an in vitro cytotoxic activity in dose-dependent manner. The IC50 values were ranging from $15 \mu \mathrm{g} / \mathrm{mL}$ to $38 \mu \mathrm{g} / \mathrm{mL}$. This activity depends not only on the extract's chemical composition (analysed by HPLC/ESI-MS), but also on the target tumor cells. Interestingly, the cytotoxic effect of these extracts on the normal human peripheral blood mononuclear cells (PBMC) was weak when compared to that induced on tumor cells. On the other hand, oral route treatment of P815 tumor-bearing mice (DBA2/P815) with propolis ethanolic extract ( $5 \mathrm{mg}$ per mouse every fourth day, five times for group A, and $2.5 \mathrm{mg}$ per mouse every fourth day, five times for group B) significantly reduced the tumor volume $\left(1.2 \mathrm{~cm}^{3}\right.$ for group $A$ and $2.7 \mathrm{~cm}^{3}$ for group B at the $22^{\text {nd }}$ day after tumor graft). These effects are statistically significant as compared to those obtained with the control untreated mice (tumor volume $3.5 \mathrm{~cm}^{3}$ at day 22).
\end{abstract}

\section{Introduction}

The propolis or bee glue is a resinous material collected by honey-bees (Apis mellifera) from the various parts of the plants (leaves, buds, flowers). This resin (propolis) contains also pollen, wax and other substances (Kosalec et al., 2004; Hegazi et al., 2002). The colour of propolis is variable from green yellow to reddish or brown black, according to the composition and the phenology of the vegetation visited by the bees (Banskota et al., 2002). The propolis is a by-product of the bee keeping and it has been known for its multiple therapeutic activities in traditional medicine since antiquity. Indeed, it was reported that the propolis exerts multiple effects such as antibacterial, antifungal, antiviral, pest-destroying (Marcucci, 1995), anti-inflammatory, antioxidant and anti-cancer activities (Borrelli et al., 2002; Banskota et al., 1998). This product has also an immuno-modulatory activity (Suzuki et al., 2002), particularly by activation of the macrophages (Orsolic et al., 2003; Almeida et al., 2002). The propolis has recently regained interest as a health food product in Taiwan, Brazil, Europe and the
United States. It is used as nutritional additive contributing to the physical good being and to the prevention of certain serious illnesses such as cancer, diabetes, cardiovascular, and inflammatory diseases (Akao et al., 2003; Chen et al., 2004). The chemical composition of the propolis depends on the vegetation from which it comes (specific composition and phenology). Many researches showed that the therapeutic effects of the propolis are mainly due to the flavonoids contained in this substance. These molecules have a very important therapeutic and cellular metabolism regulating properties (Havsteen, 1983).

The objective of this work is to investigate the chemical composition and both in vitro and in vivo, antitumor effects of two Moroccan propolis extracts (ethanolic extract EEP and ethyl acetate extract EAEP). It is reported here that EEP and EAEP had differential dose dependent cytotoxic effect on BSR cell line (kidney carcinoma of hamster), on Hep-2 cell line (human laryngeal carcinoma) and on P815 cell line (murine mastocytoma). The differential cytotoxic effect is depending on the chemical composition of the extract (analysed by HPLC/ESI-MS), and on the target tumor 
cells. Finally, an interesting in vivo antitumor effect of the EEP when orally administered in tumor bearing mice is reported.

\section{Material and Methods}

\section{Chemicals}

Dulbecco's Modified Eagles Medium (D-MEM) is from (Gibco BRL, Cergy Pontoise, France), Adriamycin, dimethyl sulfoxide (DMSO), MTT, ethyl acetate, ethanol, methanol (HPLC-grade) and Ficoll are from Sigma Chemical Co. Saint Quentin (France).

\section{The propolis and its extracts}

The propolis used in this research is collected at the end of the spring to early summer (May and June 2010), in bee-hives maintained by us in Beni Mellal region (central Morocco).The specimen voucher is deposited at the Faculty of Science and Technology Beni Mellal under reference: FSTBMCOLL72010. The vegetation in the site of propolis collection is dominated by woody species Ceratonia siliqua (Fabaceae), Olea europaea, Olea oleaster (Oleaceae) and Pistacia lentiscus (Anacardiaceae).

The ethanolic extract of propolis (EEP) is obtained by cold maceration of propolis in $95 \%$ ethanol during seven days, followed by filtration and evaporation of the solvent to dryness under vacuum. The ethyl acetate extract of propolis (EAEP) is obtained by the treatment of propolis with the ethyl acetate (95\%) in a soxhlet, followed by evaporation of the solvent to dryness under vacuum.

EEP and EAEP analysis by HPLC/ESI-MS (High performance liquid chromatography/Electro-spray ionisation Mass spectrometry)

Prior to the analysis, EEP and EAEP samples were dissolved in methanol (HPLC-grade) and filtered throw a $0.22 \mu \mathrm{m}$ syringe filter. HPLC/ESI-MS analyses were performed using a RP C18 column $(150$ x 4.6) x 5 $\mu \mathrm{m}$ with a Surveyor LC pump, Surveyor auto-sampler coupled with a PDA detector (200-600 nm), and a LCQ Advantage ( ESI) ion trap mass spectrometer (Thermo Finnigan, San Jose, CA). The injected volume was $20 \mu \mathrm{L}$ with methanol (HPLC grade) as mobile phase at a flow rate of $0.5 \mathrm{~mL} / \mathrm{min}$. ESI ionisation conditions were spray voltage $4 \mathrm{KV}$, capillary $350^{\circ} \mathrm{C}, 14 \mathrm{~V}$. Pure nitrogen is the sheath gas and pure helium was th collusion gas. The full scan mass data $\mathrm{m} / \mathrm{z}$ was obtained in both positive and negative modes and ranged from 50 to $2000 \mathrm{Da}$.

\section{Cell lines and culture}

BSR cells (kidney carcinoma of hamster fibroblast ATCC:CCL10), Hep-2 (human laryngeal carcinoma ATCC:CCL23) and P815 (mouse DBA2 mastocytoma ATCC:TIB64) come from the stock cells of the laboratory of biological engineering at the Faculty of Science and Technology Sultan Moulay Slimane University, Béni Mellal Morocco. These cells are cultured at $37^{\circ} \mathrm{C}$ in humidified atmosphere with $5 \%$ $\mathrm{CO}_{2}$ in complete culture medium (Dulbecco's Modified Eagles Medium (D-MEM) supplemented with 5\% of foetal calf serum, and $100 \mathrm{UI} / \mathrm{mL}$ of penicillin and 100 $\mu \mathrm{g} / \mathrm{mL}$ streptomycin, $0.2 \%$ sodium bicarbonate).

\section{Measurement of EEP and EAEP mediated in-vitro cytotoxicity}

This test was performed on the cell lines after six passages as previously described (Ait M'barek et al., 2007; Mossman, 1983). Briefly, tumor cells were trypsinized, when adherent, (0.15\% trypsin, $0.1 \%$ EDTA) and 1 to 1.5 x $10^{5}$ cells $/ \mathrm{mL}$ were incubated in flat-bottomed 96-well microtiter plates (Bioster, Bastia di Rovolon, Italy) in 100 $\mu \mathrm{L}$ of complete medium. Appropriate dilutions of EEP, EAEP, and adriamycin all solubilized in DMSO (final concentration of DMSO is $1 \%$ in culture) were carried out in culture medium before their addition to the cultured cells (final culture volume of $200 \mu \mathrm{L}$ ). After $48 \mathrm{~h}$ incubation in humidified atmosphere, at $37^{\circ} \mathrm{C}$ and $5 \% \mathrm{CO}_{2}, 20 \mu \mathrm{L}$ of MTT (5 mg/mL PBS) were added in each well. After 3 $\mathrm{h}$ incubation at $37{ }^{\circ} \mathrm{C}$ and $5 \% \mathrm{CO}_{2}, 100 \mu \mathrm{L}$ medium was carefully removed from each well and replaced with $100 \mu \mathrm{L}$ Isopropanol- $\mathrm{HCl}(1: 24)$. After $10 \mathrm{~min}$ incubation at $37^{\circ} \mathrm{C}$ the solubilized formazan produced by metabolically active cells was measured by scanning the 96-well plates at dualwavelength of 540-630 nm using a Multiskan apparatus (Labsystem, Helsinki, Finland). Using this colorimetric procedure, EEP, EAEP and adriamycin, cytotoxic effects could be measured as compared to the viability of untreated cells receiving DMSO ( $1 \%$ in culture) alone, according to the following calculation:

$$
\% \text { cell killing }=100 \times\left(1-\left(\mathrm{OD}_{\mathrm{t}} / \mathrm{OD}_{\mathrm{o}}\right)\right)
$$

where $\mathrm{OD}_{\mathrm{o}}$ and $\mathrm{OD}_{\mathrm{t}}$ are the optical density obtained respectively for untreated and EEP, EAEP or adriamycintreated cells. Three independent sets of experiments performed in duplicate were evaluated.

\section{Apoptosis induction analysis}

The apoptosis analysis was performed using the Anexin V Biotin-Streptavidin FITC test. Briefly, dense culture of P815 tumor cells in $25 \mathrm{~cm}^{2}$ flasks (3 
x $10^{6}$ cells in $10 \mathrm{~mL}$ DMEM), were treated with $40 \mu \mathrm{g}$ of respectively EEP or EAEP. After $12 \mathrm{~h}$ of treatment, cell pellets were PBS washed and stained with annexin V-Biotin and treated sequentially with streptavidin conjugated to fluorescein isothiocyanate (FITC) for 1 h. Then, cells were treated with the propidium iodide (PI) solution, washed with PBS and visualized with a microscope equipped with fluorescence filter (Olympus OM52) in aim to detect apoptosis induction. The assay is based on the ability of annexin V (green fluorescence) to bind to the phosphatidylserine exposed on the surface of cells undergoing apoptosis (Vermes et al., 1995).

Effect on human peripheral blood mononuclear cells (PBMC)

This test was realized in order to evaluate the effect of the tested extracts on human normal cells. To isolate the PBMC, blood samples in sterile heparinised $(10 \mathrm{~mL})$ tubes were collected under medical and ethical committee control from healthy volunteer donors. Peripheral blood mononuclear cells were isolated using standard Ficoll-hypaque density centrifugation. The interface lymphocytes were harvested and washed twice with sterile phosphate-buffered saline (PBS). EEP, EAEP and adriamycin cytotoxic effect was measured in the same conditions as detailed above for tumor cell lines.

Tumor induction in mice and treatment by propolis extracts

Mice (DBA2 $/ \mathrm{H}_{2}{ }^{\mathrm{d}}$ ), purchased from the animal breeding centre of Orleans (France), were maintained under specific pathogen-free conditions on 12-h light dark cycle. Mice were provided with sterile food and water ad libitum and were used at 6-8 weeks of age with an average weight of $20 \mathrm{~g}$. All animal experiments were performed according to the accepted principles for laboratory animal use and care of European Community guidelines. A primitive tumor isograft was induced in mice after subcutaneous injection of $5 \times 10^{6} \mathrm{P} 815\left(\mathrm{H}_{2}{ }^{\mathrm{d}}\right)$ tumor cells. When the primitive tumor reached a palpable volume, the donor mice were killed and the tumors were mechanically dissociated. Mice were then subcutaneously grafted with tumor fragments of similar size. Mice were let at rest during six days for the cicatrisation of the graft and remission from the stress. At the $6^{\text {th }}$ day after the graft the treatment was started and the tumor volume was approximately $0.1 \mathrm{~cm}^{3}$. Three sets of six mice each were assigned to each treatment group. These mice were treated in oral route by $5 \mathrm{mg}$ or $2.5 \mathrm{mg}$ EEP per mouse every four days, five times for group A and group B respectively. The control group $\mathrm{C}$ was grafted not treated (this assay is performed in triplicate). Thereafter, the tumor volume of each mouse was evaluated (careful measures with a calliper at days of treatment), according to the following calculation: tumor volume $\left(\mathrm{cm}^{3}\right)=\mathrm{D} \times \mathrm{d}^{2} / 2$, where " $\mathrm{D}$ " is the tumor length and "d" the tumor width as described by Jaafari et al. (2007) and by Yoshikawa et al. (1995).

\section{Statistical analysis}

The results are presented in the form of averages \pm SEM for assays in triplicate. The comparison of the averages is made by one way ANOVA. Differences are considered significant at $p<5 \%$.

\section{Results}

HPLC/ESI-MS analysis

The screening of EEP and EAEP by HPLC/ ESI-MS provided the data for representative samples in Figures 1 and 2. The figures show respectively (a) chromatograms of PDA scan and total ion current (TIC) in negative ESI mass, and (b) negative ESI full MS spectra. These data and according to the literature (References cited in Tables 1 and 2 relative to works on HPLC ESI-MS analyses of flavonoids), permitted to recognise deprotonated molecular ions listed in Tables 1 and 2, that may be attributed to some aglycone and glycosylated flavonoid and terpenoid molecules. The presumable presence of such compounds in the studied samples is suggested by their UV absorbancy and by the vegetation from which propolis is collected such as Olea europaea (Rovellini et al., 1997) and Ceratonia siliqua (Eldahshan, 2011). But evidently, the exact determination of the compounds requires further chromatographic and spectral analyses. Otherwise, the present data depicted the different chemical composition of the two extracts and the observed peaks revealed the complex mixture of molecules that can be found in such extracts.

In vitro cytotoxic effect of EEP and EAEP on tumor cells

The in vitro cytotoxic activity of EEP and EAEP was evaluated against Hep-2, BSR and P815 cells. The obtained results (Table 3 ) showed a concentration dependent activity. The table 3 summarises also the IC50 values for each extract. It is depicted in this table that EEP or EAEP-induced cytotoxicity varies from one cell line to another. In fact, while Hep-2 and P815 cell lines showed a comparable sensitivity to EEP (IC50 $26.01 \pm 1.3$ and $24.78 \pm 1.24 \mu \mathrm{g} / \mathrm{mL}$ respectively), the BSR cells were more sensitive to this extract (IC50 $15.61 \pm 0.78 \mu \mathrm{g} / \mathrm{mL})$. In the same way, while the levels of EAEP-induced cytotoxicity against BSR and Hep-2 cell lines were similar (IC50 18.03 \pm 0.9 and $18.31 \pm 0.91$ $\mu \mathrm{g} / \mathrm{mL}$ for BSR and Hep-2 respectively), this effect was 
weak when P815 cells were targeted (IC50 38.06 \pm 1.90 $\mu \mathrm{g} / \mathrm{mL})$. These differences are statistically significant $(p<5 \%)$. On the other hand, using the same target cells, EEP and EAEP showed a differential cytotoxic activity. Indeed EEP is more cytotoxic against P815 and BSR cells (IC50 24.78 \pm 1.24 and 15.61 $\pm 0.78 \mu \mathrm{g} /$ $\mathrm{mL}$, respectively) than EAEP (IC50 38.06 \pm 1.9 and $18.03 \pm 0.91 \mu \mathrm{g} / \mathrm{mL}$, respectively). However, when Hep-2 cell line was used as target, the EAEP-induced cytotoxicity was more important than that iduced by EEP (IC50 $18.31 \pm 0.91$ and $26.01 \pm 1.3 \mu \mathrm{g} / \mathrm{mL}$, respectively). These data indicate that the induced cytotoxicity by EEP and EAEP depends on the chemical composition of each extract and on the target tumor cell line.

\section{Detection of EEP and EAEP-induced apoptosis}

In order to contribute to the understanding of molecular mechanisms involved in the observed cytotoxic activity of EEP and EAEP extracts, apoptosis induction assay was performed using P815 tumor cell line. The obtained results are shown in Figure 3. It is depicted in this figure that treatment of these cells with EAEP induced the programmed cell death, while no apoptosis was detected in EEP-treated cells. These results suggest that EAEP may contain some components which induce apoptosis and that are absent or inactive in the EEP extract.

Evaluation of EEP and EAEP-induced cytotoxic activity against human normal peripheral blood mononuclear cells (PBMC)

In order to investigate the effects of EEP and EAEP on non tumoral cells, their cytotoxicity against PBMC was evaluated. Human normal PBMC were incubated with increasing concentrations of these extracts in the same conditions as those used for tumor cells. Figure 4 represents the percentage of cytotoxicity induced by EEP and EAEP against PBMC. In fact Sternberg et al. (2008) found that 50 micromolar pure quercetin induced $20 \%$ proliferation reduction in PBMC. It is shown in this figure that EEP and EAEP exhibit a small cytotoxic (at high dose of $65 \mu \mathrm{g}$ and more) effect as compared to that

Table 1. Presumable flavonoid molecular and fragment ions detected in negative ionisation mode for EAEP.

\begin{tabular}{lcc}
\hline \multicolumn{1}{c}{ Compounds } & $m / z[\mathrm{M}-\mathrm{H}]-$ & References \\
\hline wogonoside & 919 & Han et al., 2007 \\
quercetin arabino-glucoside & 595462301 & Engels et al., 2011 \\
apigenin dihexoside & 563443259 & Han et al., 2007; Li et al 2011 \\
rhamnetin hexoside) & 477315300 & Han et al., 2007; Ding et al., 2008 \\
baicalin or wogonin glucoside & 445 & Han et al., 2007 \\
rhamnetin or isorhamnetin & 315300271 & Engels et al,. 2011; Ding et al., 2008 \\
kaempferide or trihydroximethoxiflavone & 299284255 & Han et al., 2007; Engels et al,. 2011 \\
\hline
\end{tabular}

Table 2. Presumable flavonoid molecular and fragment ions for EEP detected in negative ionisation mode.

\begin{tabular}{lcc}
\hline \multicolumn{1}{c}{ Presumable compounds } & $m / z[\mathrm{M}-\mathrm{H}]-$ & References \\
\hline luteolin & 285 & Marques et al., 2009 \\
luteolin-7-O-glucoside & 447287 & Han et al., 2007; Marques et al., 2009 \\
kaempferol $O$-glucoside & 447301300271151 & Engels et al,. 2011; Ding et al., 2008 \\
apigenin & 269 & Han et al. 2007; Marques et al. 2009 \\
daphnin or daphnitin & 339151679 Sira & Marques et al., 2009 \\
wogonin or dihydroxy methoxyflavone & 283 & Han et al., 2007 \\
caffeic acid & $389(195)$ & Simirgiotis et al., 2012 \\
naringenin or pinobanksin & 271 & Sun et al., 2007 \\
kaempferide & 299 & Engels et al., 2011 \\
quercetin 3- $O$-pentoside & 433 & Engels et al. 2011 \\
isorhamnetin & 315 & Engels et al., 2011; Ding et al., 2008 \\
dihydroxyflavone & 247 & Pietta et al., 2002 \\
afzelekin-catechin dimer & 561 & Simirgiotis et al., 2012 \\
quercetin dipentoside & 565 & Engels et al., 2011 \\
\hline
\end{tabular}



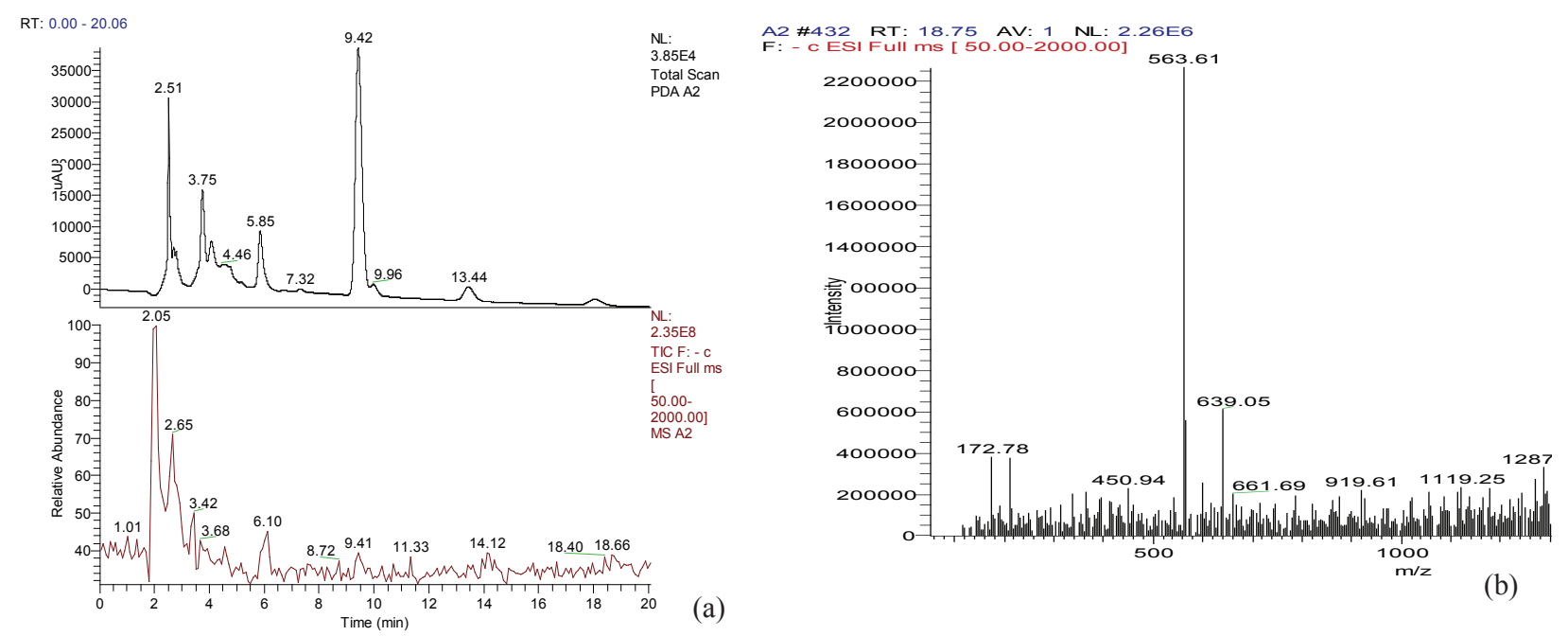

Figure 1. Representative HPLC-ESI-MS analysis of EAEP sample. Respectively (a) PDA Chromatograms and TIC MS scan. (b). Full scan MS.
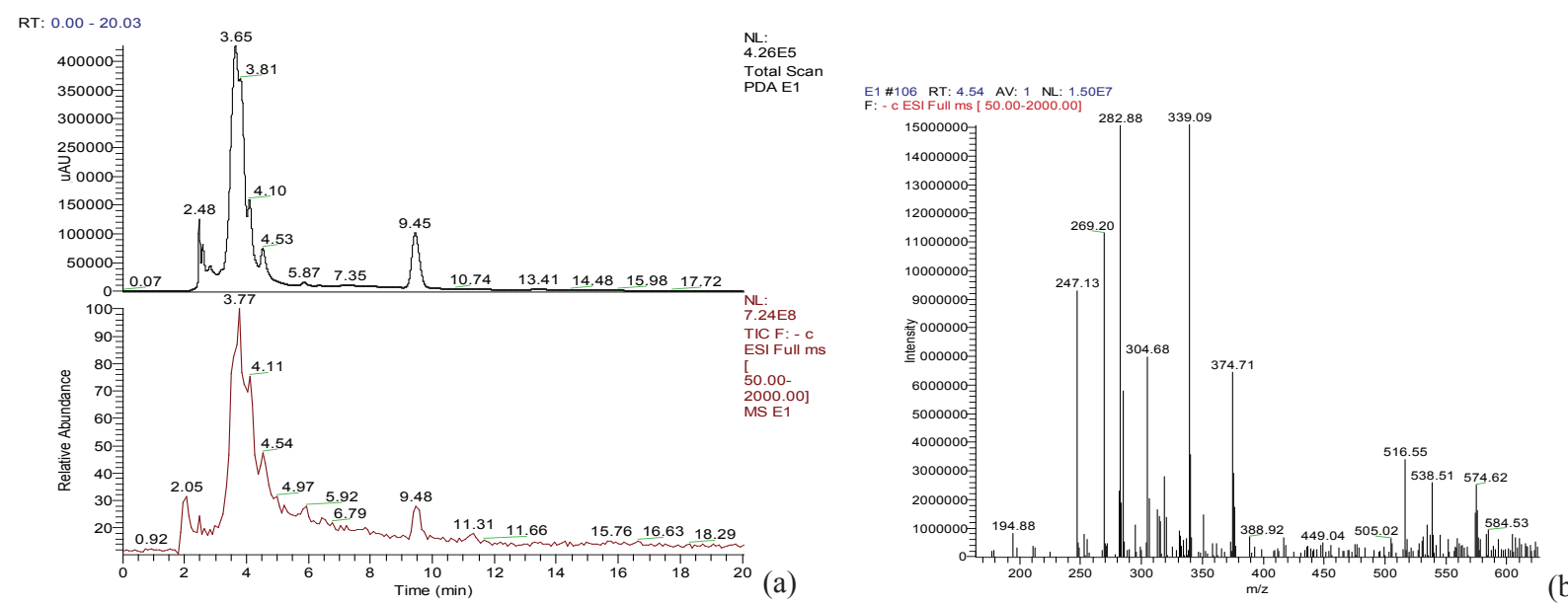

Figure 2. Representative HPLC-ESI-MS analysis of EEP sample. Respectively (a) PDA Chromatograms and TIC MS scan. (b) Full scan MS.

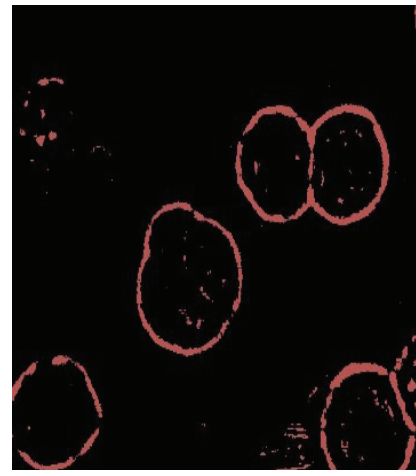

Untreated cells

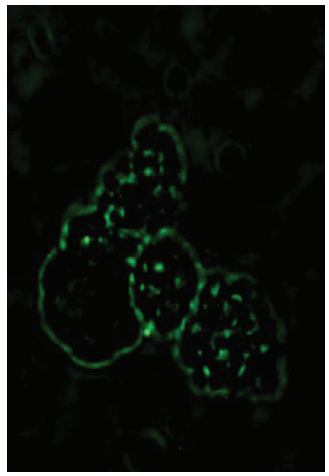

EAEP-treated cells

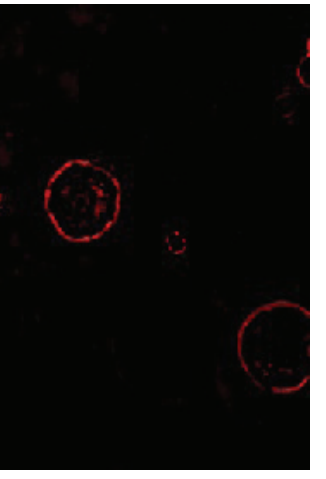

EEP-treated cells

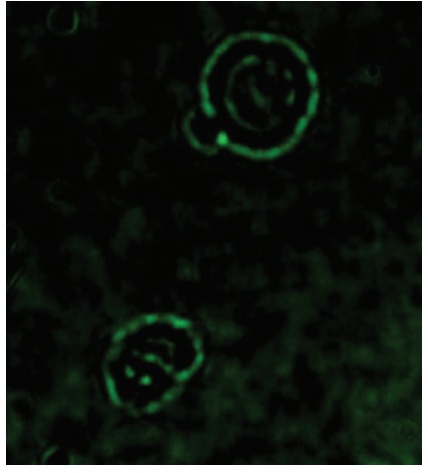

Positive control

Figure 3. Apoptosis induction analysis in P815 cells. P815 tumor cells ( 3 x $10^{6}$ cells) were treated with $40 \mu \mathrm{g}$ of respectively EEP or EAEP. After $12 \mathrm{~h}$ of treatment, cell pellets were PBS washed and stained with annexin V-Biotin and treated sequentially with streptavidin-FITC for $1 \mathrm{~h}$. Then, cells were treated with the propidium iodide (PI) solution, washed with PBS and visualized with a microscope equipped with fluorescence filter in aim to detect apoptosis induction. The assay is based on the ability of annexin $\mathrm{V}$ (green fluorescence) to bind to the phosphatidylserine exposed on the surface of cells undergoing apoptosis. Positive control: serum starvation. 


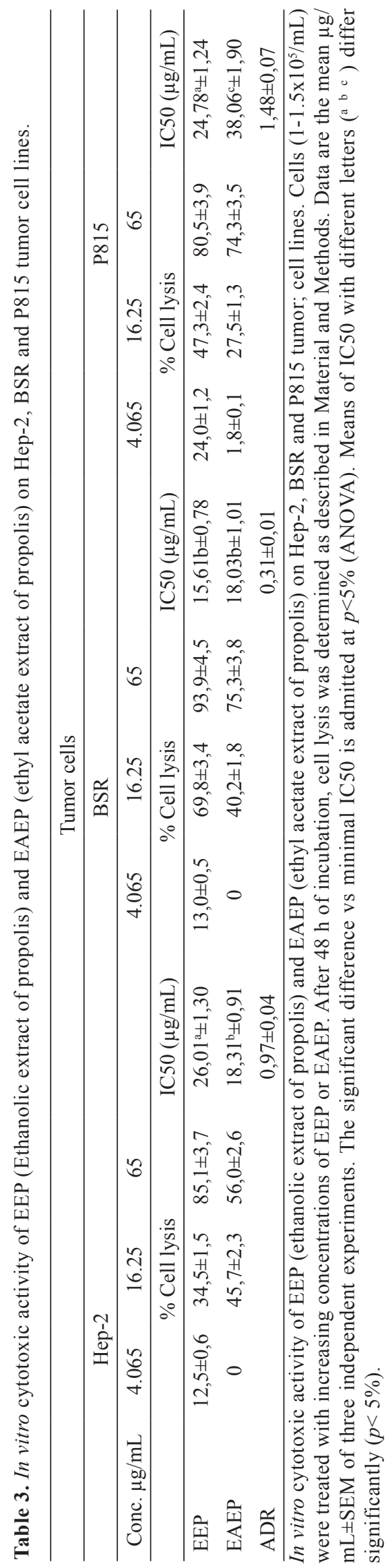

exerted on cancer cells. Furthermore, considering the applied doses, these results indicate that normal human PBMC were more resistant to EEP and EAEP-induced cytotoxicity than cancer cells, and suggest that these extracts may act selectively on tumor cells.

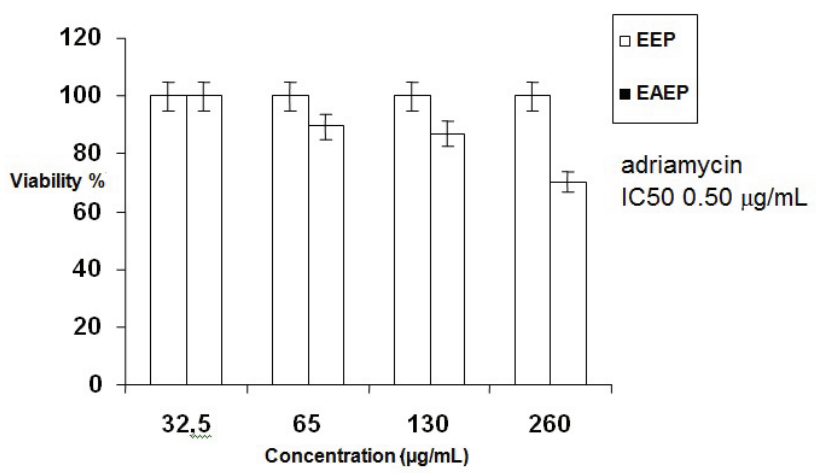

Figure 4. Percent viability of human PBMC treated with EEP (ethanolic extract of propolis) and EAEP (ethyl acetate extract of propolis). Cells from healthy human donors are isolated and cultured as detailed in material and methods, and were treated with high doses of EEP and EAEP. Data are means \pm SEM of three experiments in duplicate.

\section{Effect of ethanolic extract of propolis (EEP) on tumor volume evolution in mice}

In order to find out any clinical relevance of in vitro findings, in vivo experiments using the $\mathrm{DBA}_{2}\left(\mathrm{H}_{2}{ }^{\mathrm{d}}\right)$ P815 tumor cell line (H2d) model were performed (Ait M'Barek et al., 2007). Since EEP was the most in vitro cytotoxic extract against P815 cell line, it was used to validate the in vitro observations. Figure 5 shows the effect of the treatment with two different doses of EEP on tumor volume evolution in the tumor-bearing mice. It is depicted in this figure that at day 6 after the graft (first day of treatment), the tumor volume was about $0.20 \pm 0.01$ $\mathrm{cm}^{3}$ for all tested groups. However, the oral administration of EEP $(5 \mathrm{mg} / \mathrm{mouse}$ and $2.5 \mathrm{mg} / \mathrm{mouse}$ every fourth day for group A and for group B, respectively) significantly reduced solid tumor development in the treated groups compared to untreated mice (group C) $p<5 \%$ at the $17^{\text {th }}$ day. On the $22^{\text {nd }}$ day ( $16^{\text {th }}$ day of treatment), the tumor volume of the control animals was $3.6 \pm 0.20 \mathrm{~cm}^{3}$ (group C), whereas that of treated animals was $1.30 \pm 0.10 \mathrm{~cm}^{3}$ and $2.70 \pm 0.16 \mathrm{~cm}^{3}$ for groups $\mathrm{A}$ and $\mathrm{B}$, respectively. This difference was found to be significant between control and treated groups $(p<1 \%)$. Interestingly, a significant difference was observed between treated groups (group A and B), starting from the $14^{\text {th }}$ day ( $8^{\text {th }}$ day of treatment $)$ $(p<5 \%)$. This difference becomes more important at the $22^{\text {nd }}$ day $(p<1 \%)$. 


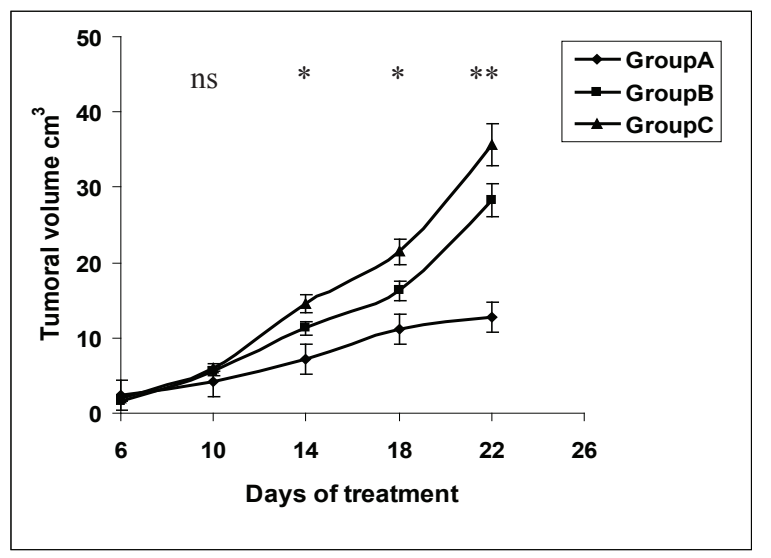

Figure 5. Evolution of tumor volume in EEP treated DBA2 $\left(\mathrm{H}_{2}{ }^{\mathrm{d}}\right)$ P815 tumor bearing mice. Mice were subcutaneously grafted by the P815 tumor cell line ( $\mathrm{H}_{2}{ }^{\mathrm{d}}$ haplotype). Group A and Group B are treated by ethanolic extract of propolis (EEP) respectively at the amount of $5 \mathrm{mg}$ and $2.5 \mathrm{mg} /$ mice every fourth day, five times during 22 days as described in material and methods. The Group $\mathrm{C}$ is the control non-treated group. (ns: no significant difference; ${ }^{*} p<5 \%$ and ${ }^{* *} p<1 \%$ versus control group ANOVA one way). Groups contain six mice in triplicate.

\section{Discussion}

This study was undertaken to provide a comparative data on the cytotoxic activity of two different extracts of Moroccan propolis against various tumor cell lines. For the first time, we report an effective and differential cytotoxic effect of these extracts against the used target cell lines. This differential activity was related not only to the chemical composition of the extracts, but also to the nature of the tumor cell lines. Indeed, while Hep-2 and P815 cells showed a comparative sensitivity to EEP (IC50 26.01 \pm 1.30 and $24.78 \pm 1.20 \mu \mathrm{g} / \mathrm{mL}$, respectively), the $\mathrm{BSR}$ cells are more sensitive to this extract (IC50 15.61 $\pm 0.78 \mu \mathrm{g} / \mathrm{mL}$ ). In addition, while EAEP-induced cytotoxicity levels against BSR and Hep-2 were similar (IC50 18.03 \pm 1.01 and $18.31 \pm 0.91 \mu \mathrm{g} / \mathrm{mL}$ for BSR and Hep-2 cells respectively), the effect against P815 cell line was weak (IC50 38.56 $\pm 1.9 \mu \mathrm{g} / \mathrm{mL}$ ). Finally, using the same target cells, EEP and EAEP showed very different levels of cytotoxicity except for BSR cells. The differential effect of these extracts on the same cell line may be related to the differential chemical composition of such extracts. The present data are in agreement with those of (Akao et al., 2003), and (Chen et al., 2004), who reported that the cytotoxic effect of ethanolic extracts of several samples of propolis and their hexane and ethyl acetate fractions depend on the flavonoid contents of these extracts; and this effect is increased by other molecules which are found in the ethanolic extract. The tentative of molecular analysis of Moroccan propolis extracts by modern hyphened techniques, HPLC-MS, is reported for the first time. The probably composition is comparable to molecules and compounds found in samples from other regions (Pietta et al., 2002). The exact determination of this molecular composition requires further chromatographic and spectral studies. On the other hand, the interaction between these molecules ant the cell components remains to be established. Indeed, quercetin a current compound of propolis was cited as a potential modulator of P-glycoprotein expression and function in human pancreatic carcinoma cells resistant to daunorubicin (Borska et al., 2010). BiochaninA and silymarin elso found in propolis can inhibit Pgp mediated efflux of digoxin and vinblastin in human intestinal Caco-2 cells suggesting that these molecules can icrease the bio-availability of anti-tumoral administred drugs (Zhang \& Morris 2003). Furthermore, if the differential chemical composition of these two extracts may explain the different levels of sensitivity of the same cell line to these extracts, it could not explain why each extract (EEP or EAEP) exhibit a differential and selective cytotoxic effect from one cell line to another. The obtained results demonstrate that the cytotoxicity of EEP and EAEP is target cell-dependent. This idea was also confirmed when we tested EEP and EAEP towards normal human peripheral blood mononuclear cells (PBMC). These experiments were performed to evaluate the side effects of these extracts. In fact, only minimal cytotoxicity against the PBMC was observed for the two studied extracts. These results are in agreement with those of Dimov et al. (1991), who reported an immune-modulmatory activity of propolis. In fact propolis exert an immune-modulatory effect on natural killer cells (Sforcin et al., 2002), and on macrophages (Scheller et al., 1989). The molecular mechanism of propolis-induced in vitro cytotoxicity is not well documented. In order to contribute to the understanding of the molecular mechanisms involved in the observed cytotoxic activity of EEP and EAEP extracts, apoptosis induction experiments were performed using P815 tumor cell line. The assay results showed that treatment of these cells with EAEP induced the programmed cell death, while no apoptosis was detected in EEP-treated cells. These results suggest that EAEP may contain some components which induce apoptosis and that are absent or inactive in the EEP extract. Araujo et al. (2010), observed that the cytotoxicity of propolis ethanolic extract may be related to its chemical composition and to the inhibition of nitric oxide (NO) production.

Since EEP, was the extract with the highest in vitro cytotoxic activity compared to EAEP, it was used to validate in vitro findings using P815 tumor-bearing DBA2 $\left(\mathrm{H}_{2}{ }^{\mathrm{d}}\right)$ mice model. When administered EEP by oral route, a significant regression of tumor volume in time-and dose-dependent manner was observed in treated groups, while the control group exhibited an increasing tumor volume (Figure 5). These results confirm those of 
Scheller et al. (1989), who observed a cytotoxic effect of ethanolic extract of propolis in mice-bearing Ehrlich carcinoma. They also complete the work of Suzuki et al. (2002), demonstrating that subcutaneous administration of crude water-soluble derivative of propolis resulted in marked regression of tumor growth in mice at the early phase after tumor inoculation. In the same way, Orsolic et al. (2005), reported antitumor effect of water-soluble derivative of propolis.

The mode of in vivo administration of anticancer products is an important problem, and it can lead to differential results depending on the used mode. Hollands et al. (1991) reported that propolis has low acute oral toxicity, as shown by LD50 when tested in mice (2000 to $7300 \mathrm{mg} / \mathrm{kg}$ body weight, and flavonoids tested in rats (4000 to $8000 \mathrm{mg} / \mathrm{kg}$ body weight). Decastro \& Higashi (1995) reported no side effects of propolis in oral administration to mice as high as $4000 \mathrm{mg} / \mathrm{kg} /$ day for two weeks, and in drinking water at $1.4 \mathrm{mg} / \mathrm{kg} /$ day for ninety days (Kaneeda \& Nishina, 1994).

The mechanism involved in propolis extracts induced cytotoxicity in mice is still unknown. However, the ethanolic extract may act via a direct cytotoxic activity by alteration of biological membranes under the action of natural flavone molecules (Herrerias et al. 2010) or by DNA-binding of flavonoid aglycone or flavoloid glycosides compromising DNA duplication and leading to the cell cycle arrest (Wang et al., 2008). It can also act in vivo via a stimulation of multicellular immunity including lymphocyte proliferation (Sà Nunes et al., 2003), natural killer cells and macrophages activation (Dimov et al., 1991; Orsi et al., 2000). The synergistic effects of these two ways, as well as the part of each one in neutralising tumor cells need more investigations.

In conclusion, the present study demonstrates that the cytotoxic activity of EEP and EAEP extracts is a complex phenomenon depending not only on the nature of the extract and its components, but also on the tumor cell type. The present assays report an effective reduction of the tumor volume by the ethanolic extract of propolis in P815 tumor bearing mice and apoptotis induction in P815 Cells. Additional research is running in our laboratory to determine the compounds responsible for these in vitro and in vivo anticancer activities as well as the molecular mechanisms involved in their effects.

\section{Acknowledgment}

The authors would like to thank Prof. Zacharie Brahmi (The Children's Hospital of Indianapolis, USA), for reviewing the manuscript. This work was supported by a grant from the CNRST (PROTARSIII, D61/07), Rabat, Morocco.

\section{References}

Ait Mbarek L, Ait Mouse H, ELAbbadi N, Bensalah M, Gamouh A, Aboufatima R, Benharref A, Chait A, Kamal M, Dalal A, Zyad A 2007. Anti-tumor properties of blackseed (Nigella sativa L.) extracts. Braz J Med Biol Res 40: 839-847.

Akao Y, Maruyama H, Matsumoto K, Ohguchi K, Nishizawa $\mathrm{K}$, Sakamato T, Araki Y, Mishima S, Nozawa Y 2003. Cell growth inhibitory effect of cinnamic acid derivatives from propolis on human tumor cell lines. Biol Pharmaceut Bull 26: 1057-1059.

Almeida EC, Menezes H 2002. Anti-inflammatory activity of propolis extracts: A Review. J Venom Anim Toxins 8: 191-212.

Araujo Maria José AM, Dutra RP, Costa GC, Reis AS, Assunção AKM, Libério SA, Maciel MCG, Silva LA, Guerra, RNM, Ribeiro MNS, Nascimento FRF 2010. Effect of propolis of Scaptotrigona aff. postica on the development of the tumor of Ehrlich in mice. Rev Bras Farmacogn 20: 580-587.

Borska S, Sopel M, Chmielewska M, Zabel M, Driegiel P 2010. Quercetin as apotential modulator of P-glycoprotein expression and function in cells of human pancreatic carcinoma line resistant to daunorubicin. Molecules 15: 857-870.

Banskota AH, Nagaoka T, Sumioka LY, Awale S, Midorikawa K, Matsushige K, Kadota S 2002. Antiproliferative activity of the Netherlands propolis and its active principles in cancer cell lines. J Ethnopharmacol 80: 67-73.

Banskota AH, Tezuka Y, Prasain JK, Matsushige K, Saiki I, Kadota S 1998. Chemical constituents of Brazilian propolis and their cytotoxic activities. J Nat Prod 61: 896-900.

Borrelli F, Izzo AA, Di Carlo G, Maffia P, Russo A, Maiello FM, Capasso F, Mascolo N 2002. Effect of a propolis extract and caffeic acic phenethyl ester on formation of aberrant crypt foci and tumors in the rat colon. Fitoterapia 73 suppl: 38-43.

Chen CN, Weng MS, Wu CL, Lin JK 2004. Comparison of radical scavenging activity, cytotoxic effects and apoptosis induction in human melanoma cells by Taiwanese propolis from different sources. Evid Based Complement Alternat Med 2: 175-185.

Decastro SL, Higashi KO 1995. Effect of different formulations of propolis on mice infected with Trypanosoma cruzi. $J$ Ethnopharmacol 46: 55-58.

Dimov V, Ivanovska N, Manolova N, Bankova V, Nikolov N, Popov S 1991. Immuno-modulatory action of propolis. Influence of anti-infectious protection and macrophage function. Apidologie 22: 65-62.

Ding S, Dudley E, Plummer S, Tang J, Newton RP, Brenton AG 2008. Fingerprint profile of Ginkgo biloba nutritional supplements by LC/ESI-MS/MS. Phytochemistry 69: 
$1555-1564$.

Engels C, Grater D, Esquivel P, Jimenez VM 2011. Characterization of phenolic compounds in jocote (Spondias purpurea L.) peels by ultra high-performance liquid chromatography/electrospray ionization mass spectrometry. Food Res Int doi 10. 1016/j.foodres 2011.04.003.

Eldahshan OA 2011. Isolation and structure elucidation of phenolic compounds of carob leaves grown in Egypt. Curr Res J Biol Sci 3: 52-55.

Han J, Ye M, Sun J, Wang B, Guo D 2007. Characterisation of flavonoids in the traditional Chinese medicine-huangqin by liquid chromatography coupled with electrospray ionization mass spectrometry. $J$ Chromatogr $B$ 848: 355-362.

Havsteen B 1983. Flavonoids, a class of natural products of high pharmacological potency. Biochem Pharmacol 32: 1141-1148.

Hegazi AG, Abd El Hady FK 2002. Egyptian propolis: 3. Antioxydant, antimicrobial activities and chemical composition of propolis from reclaimed lands. $Z$ Naturforsch 57c: 395-402.

Herrerias T, Oliveira AA, Belem ML, Oliveira BH, Carnieri EGS, Cadena SMSC, Noleto GR, Martinez GR, Oliveira MBM, Rocha MEM 2010. Effects of natural flavones on membrane properties an cytotoxicity of $\mathrm{HeLa}$ cells. Rev Bras Farmacogn 20: 403-408.

Hollands I, Vidal A, Gra B, Sotolongo M 1991. Evaluation of the subchronic toxicity of Cuban propolis. Rev Cubana Cienc Vet 22: 91-100.

Jaafari A, Ait Mouse H, Rakib EM, Ait M'barek L, Tilaoui M, Benbakhta C, Boulli A, Abbad A, Zyad A 2007. Chemical composition and antitumor activity of different wild varieties of Moroccan thyme. Rev Bras Farmacogn 17: 477-491.

Kaneeda J, Nishina T 1994. Safety of propolis: acute toxicity. Honney Bee Sci 15: 29-33.

Kosalec I, Bakmaz M, Pepeljnjak S, Voknizevic S 2004. Quantitative analysis of the flavonoids in raw propolis from northern Croatia. Acta Pharm 54: 65-72.

Li W, Qiu Y, Patterson CA, Beta T 2011. The analysis of phenolic constituents in glabrous canaryseed groats. Food Chem 127: 10-20.

Marcucci MC 1995. Propolis: chemical composition, biological properties and therapeutics activity. Apidologie 26: 8399.

Marques R, Sousa MM, Oliveira MC, Melo MJ 2009. Characterization of weld (Reseda luteola L.) and spurge fax (Daphne gnidium L.) by high performance liquid chromatography-diode array detection- mass spectrometry in Arraiolos historical textiles. $J$ Chromatogr A 1216: 1395-1402.

Mossman T 1983. Rapid colorimetric assay for cellular growth and survival: application to proliferation and cytotoxic assays. J Immunol Methods 65: 55-63.
Orsi RO, Funari SRC, Soares AMVC, Calvi SA, Oliveira SL, Sforcin JM, Bankova V 2000. Immuno-modulatory action of propolis on macrophage activation. $J$ Venom Anim Toxins 6: 205-219.

Orsolic N, Terzic S, Sver L, Basic I 2005. Honey bee products in prevention and/or therapy in murine transplantable tumours. J Sci Food Agric 85: 363-370.

Orsolic N, Basiç I 2003. Immunomodulation by water-soluble derivative of propolis: a factor of antitumor reactivity. $J$ Ethnopharmacol 84: 265-273.

Pietta PG, Gardana C, Pietta AM 2002. Analytical methods for quality control of propolis. Fitoterapia 73 Suppl. 1: S7S20.

Rovellini P, Cortesi N, Fedeli E 1997. Analysis of flavonoids from Olea europaea by HPLC-UV and HPLCelectrospray-MS. Rev Ital Sust Gras 74: 273-279.

Sà Nunes A, Faccioli LH, Sforcin JM 2003. Propolis: lymphocyte proliferation and IFN- $\gamma$ production. $J$ Ethnopharmacol 8: 93-97.

Scheller S, Krol W, Swiacik J, Owczarek S, Gabrys J, Shani J 1989. Antitumoral property of ethanolic extract of propolis in mice-bearing Ehrlich carcinoma, as compared to bleomycin. Z Naturforsch 44c: 10631065.

Sforcin JM, Kaneno R, Funari SRC 2002. Absence of seasonal effect on the immuno-modulatory action of Brazilian propolis on natural killer activity. J Venom Anim Toxins 8: 19-29.

Simirgiotis MJ, Silva M, Becerra J, Schmeda-Hirschman G 2012. Direct characterization of phenolic antioxidants in infusions from four Mapuche medicinal plants by liquid chromatography with diode array detection (HPLC-DAD) and electrospray ionization tandem mass spectrometry (HPLC-ESI6MS). Food Chem 131: 318327.

Sternberg Z, Chadha K, Lieberman A, Hojnacki D, Drake A, Zamboni P, Rocco P, Grazioli E, Weinstock-Guttman $\mathrm{B}$, Munschauer F 2008. Quercetin and interferon $\beta$ modulate immune response(s) in PBMC isolated from multiple sclerosis patients. J Neuroimmunol 205: 142147.

Sun J, Liang F, Bin Y, Li P, Duan C 2007. Screening non-coloured phenolics in red wines using liquid chromatography/ ultraviolet and mass spectrometry/ mass spectrometry libraries. Molecules 12: 679-693.

Suzuki I, Hayashi I, Takaki T, Groveman DS, Fujimiya $Y$ 2002. Antitumor and anticytopenic effects of aqueous extracts of propolis in combination with chemotherapeutic agents. Cancer Biother Radiopharm 17: 553-562.

Vermes I, Haanen C, Steffens-Nakken H, Reutlingsperger C 1995. A novel assay for apoptosis. Flow cytometric detection of phosphatidylserine expression on early apoptotic cells using fluorescein labelled Annexin V. $J$ Immunol Methods 184: 39-51. 
Wang Z, Cui M ,Song F, Lu L, Liu Z 2008. Evaluation of flavonoids binding to DNA duplexes by electorspray ionization mass spectrometry. J Am Soc Mass Spectrom 19: 919-922.

Yoshikawa T, Kokura S, Naito Y, Kondo MA 1995. Novel cancer therapy based on oxygen radicals. Cancer Res 55: 1617-1620.

Zhang S, Morris ME 2003. Effect of the flavonoids biochanin A and silymarin on the P-glycoprotein mediated transport of digoxin and vinblastin in human intestinal Caco-2 cells. Pharm Res 20: 1184-1191.

\section{*Correspondence}

Abdelmajid Zyad

Laboratory of Biological Engineering, Faculty of Science and Technology

Box 523, Béni-Mellal 23000, Morocco

a.zyad@fstbm.ac.ma

Tel. +212 234851 12/22/82 ext. 289/261

Fax: +21223485201 